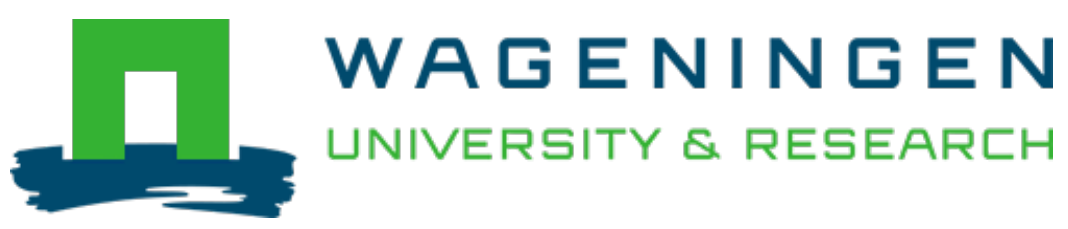

\author{
First characterization of bioactive components in soybean tempe that protect \\ human and animal intestinal cells against enterotoxigenic Escherichia coli (ETEC) \\ infection \\ Journal of Agricultural and Food Chemistry \\ Roubos-van den Hil, P.J.; Schols, H.A.; Nout, M.J.R.; Zwietering, M.H.; Gruppen, H. \\ https://doi.org/10.1021/jf101379y
}

This publication is made publicly available in the institutional repository of Wageningen University and Research, under the terms of article $25 \mathrm{fa}$ of the Dutch Copyright Act, also known as the Amendment Taverne. This has been done with explicit consent by the author.

Article $25 \mathrm{fa}$ states that the author of a short scientific work funded either wholly or partially by Dutch public funds is entitled to make that work publicly available for no consideration following a reasonable period of time after the work was first published, provided that clear reference is made to the source of the first publication of the work.

This publication is distributed under The Association of Universities in the Netherlands (VSNU) 'Article $25 \mathrm{fa}$ implementation' project. In this project research outputs of researchers employed by Dutch Universities that comply with the legal requirements of Article 25fa of the Dutch Copyright Act are distributed online and free of cost or other barriers in institutional repositories. Research outputs are distributed six months after their first online publication in the original published version and with proper attribution to the source of the original publication.

You are permitted to download and use the publication for personal purposes. All rights remain with the author(s) and / or copyright owner(s) of this work. Any use of the publication or parts of it other than authorised under article $25 \mathrm{fa}$ of the Dutch Copyright act is prohibited. Wageningen University \& Research and the author(s) of this publication shall not be held responsible or liable for any damages resulting from your (re)use of this publication.

For questions regarding the public availability of this publication please contact openscience.library@wur.nl 


\title{
First Characterization of Bioactive Components in Soybean Tempe That Protect Human and Animal Intestinal Cells against Enterotoxigenic Escherichia coli (ETEC) Infection
}

\author{
Petra J. Roubos-van den Hil, ${ }^{*}, \dagger$ Henk A. Schols,${ }^{\star}$ M. J. Rob Nout, ${ }^{\dagger}$ \\ Marcel H. Zwietering, ${ }^{\dagger}$ and Harry Gruppen ${ }^{\star}$ \\ ${ }^{\dagger}$ Laboratory of Food Microbiology and ${ }^{\star L}$ aboratory of Food Chemistry, Wageningen University, \\ Bomenweg 2, 6703 HD Wageningen, The Netherlands
}

\begin{abstract}
Tempe extracts can inhibit the adhesion of enterotoxigenic Escherichia coli (ETEC) to intestinal cells and thereby can play a role in controlling ETEC-induced diarrhea. The component responsible for this adhesion inhibition activity is still unknown. This research describes the purification and partial characterization of this bioactive component of tempe. After heating, defatting, and protease treatment, the extracts were found to remain active. However, after treatment with polysaccharidedegrading enzyme mixtures the bioactivity was lost. Ultrafiltration revealed the active component to be $>30 \mathrm{kDa}$. Further purification of the bioactive tempe extracts yielded an active fraction with an increased carbohydrate content of higher arabinose content than the nonactive fractions. In conclusion, the bioactive component contains arabinose and originates from the arabinan or arabinogalactan side chain of the pectic cell wall polysaccharides of the soybeans, which is probably released or formed during fermentation by enzymatic modifications.
\end{abstract}

KEYWORDS: Bioactivity; adhesion; soybeans; fermentation; polysaccharides; $E$. coli; tempeh; diarrhea

\section{INTRODUCTION}

Diarrheal diseases of humans and farm animals are frequently caused by infection with enterotoxigenic Escherichia coli (ETEC). ETEC strains are associated with two major human clinical syndromes: weanling diarrhea among children in developing countries and traveler's diarrhea $(1,2)$. ETEC is also an important and global cause of severe, watery diarrhea in the offspring of some animal species such as newborn calves and suckling and weaned pigs (3).

Adhesion of ETEC to intestinal epithelium is known to be a prerequisite for colonization and infection of the intestinal tract. Adhesion of ETEC onto the small intestinal microvilli does not cause significant morphological changes, but it is a requirement for the secretion of enterotoxins that alter the behavior of the enterocytes by increasing secretion and/or reducing absorption (3).

The adhesion of ETEC bacteria to intestinal epithelial cells can be mediated by (proteinaceous) fimbriae. These fimbriae bind to carbohydrate-specific receptors (binding sites) at the epithelial cell surface. Inhibition of adhesion can be due to carbohydrate epitopes that are structurally similar to the binding sites of the epithelial cells and, therefore, adhere to the bacteria and act by competitive inhibition. Nonadhering bacteria are subsequently removed by regular bowel-cleansing mechanisms (4-6). Human breast milk oligosaccharides are known to act as these so-called antiadhesins (7).

*Corresponding author (phone +31-317-484982; fax +31-317484978; e-mail Petra.roubos@wur.nl).
Other studies have concluded that proteinaceous components released from lactic acid bacteria decrease the adhesion of ETEC to piglet ileal mucus (8). Also, bifidobacteria are known to secrete a proteinaceous component that prevents the adhesion of ETEC to intestinal epithelial cell lines (9). This adhesion inhibition can be due to competitive exclusion between bacteria, steric hindrance, or chemical changes of adhesion receptors of the epithelial cells.

Tempe is a traditional, fermented soybean product made from dehulled, soaked, and cooked soybeans inoculated with mold, usually a Rhizopus species. During the fermentation, mycelial biomass is formed and the fungal enzymes breakdown the soybean macromolecules. This contributes to the development of a desirable texture and flavor in the product. It also inactivates or eliminates some soy antinutritional components (10).

Carbohydrases are used in piglet diets to improve nutrient utilization, and it has been reported that the addition of certain carbohydrases to piglet diets reduced the frequency and severity of diarrhea (11). Other research showed that the hydrolysis products of nonstarch polysaccharides of soybean meal are beneficial in fluid balance during ETEC infection (12). The enzymatic activity during fermentation could give the same beneficial effects to the soybeans.

Earlier research indicated that the severity of diarrhea in ETEC-induced weaned piglets was less when these piglets were fed tempe instead of toasted soybeans (13). Kiers et al. investigated the effect of tempe on fluid absorption in piglets and suggested that a water-soluble, high molecular mass fraction $(>5 \mathrm{kDa}$ ) of tempe is able to protect against fluid losses induced 
Table 1. Overview of Carbohydrases Used

\begin{tabular}{|c|c|c|c|}
\hline name & abbreviation & main substrate(s) & source \\
\hline endo- $\beta-1,4$-galactanase ${ }^{a, b}$ & GAL & galactan & Aspergillus niger \\
\hline arabinofuranosidase $A^{b, c}$ & ARA-A & arabinan & Aspergillus niger \\
\hline arabinofuranosidase $\mathrm{B}^{b, c}$ & ARA-B & arabinan & Aspergillus niger \\
\hline$\alpha$-mannosidase ${ }^{d}$ & $\alpha-M A N$ & mannan & jack beans \\
\hline endo- $\beta$-mannanase ${ }^{e}$ & $\beta$-MAN & mannan & Aspergillus niger \\
\hline gammanase $e^{f}$ & GAM & mannan & \\
\hline mix of GAL, ARA-A, and ARA-B & $\mathrm{GAL}+\mathrm{ARA}$ & (arabino)galactan, arabinan & \\
\hline Driselase ${ }^{d}$ & DRI & pectin, hemicellulose & basidomycetes \\
\hline Pectinex Ultra SP-L ${ }^{f}$ & PEC & pectin, hemicellulose & Aspergillus aculeatus \\
\hline Rapidase Liq $+{ }^{b}$ & LIQ & pectin, hemicellulose & \\
\hline
\end{tabular}

${ }^{a}$ Purified by Van de Vis et al. (28). ${ }^{b}$ Supplied by DSM, Delft, The Netherlands. ${ }^{c}$ Purified by Rombouts et al. (29). ${ }^{d}$ Supplied by Sigma, St. Louis, MO. ${ }^{e}$ Supplied by Megazyme, Bray, Wicklow, Ireland. ${ }^{t}$ Supplied by Novozymes, Bagsvaerd, Denmark.

by ETEC. As a consequence, this fraction could thus play a role in controlling ETEC-induced diarrhea (14). Furthermore, tempe extracts can inhibit the adhesion of ETEC to intestinal epithelial cells in both piglet brush border cells (15) and human epithelial (Caco-2) cells (16). Tempe extracts were found to interact with ETEC bacteria and could possibly form a layer coating (part of) the bacterial surface, which may contribute to the observed decrease of ETEC adhesion to intestinal epithelial cells (16).

In this research we describe the characterization of the bioactive components in tempe, which inhibit adhesion of ETEC to intestinal cells.

\section{MATERIAL AND METHODS}

Materials. Dehulled yellow seeded soybeans (Glycine max) were supplied by Kleinjan VOF (Rhoon, The Netherlands). Malt extract agar (MEA) and peptone were purchased from Oxoid (Basingstoke, U.K.). Brain-heart infusion broth (BHI) was purchased from Becton Dickinson (Sparks, MD). Enzymes were obtained from various sources as described in Table 1. All other chemicals were purchased from Merck (Darmstadt, Germany) or Sigma (St. Louis, MO).

Tempe Preparation. Dehulled, full-fat yellow-seeded soybeans were soaked overnight in tap water using three cycles of accelerated acidification at $30^{\circ} \mathrm{C}(17)$. Next, the beans were washed with tap water and cooked in fresh tap water for $20 \mathrm{~min}$ in a bean/water ratio of 1:3 (v/v). Subsequently, the beans were cooled and superficially dried at room temperature on perforated trays. For the fungal inoculation of the soybeans a sporangiospore suspension was used. The suspension was prepared by scraping off the sporangia from pure slant cultures of Rhizopus microsporus var. microsporus (LU573) grown on MEA for 7 days at $30^{\circ} \mathrm{C}$ and suspending them in sterile distilled water with $0.85 \%(\mathrm{w} / \mathrm{v}) \mathrm{NaCl}$ and $0.1 \%(\mathrm{w} / \mathrm{v})$ peptone (PPS). After inoculation of the cooked beans with the sporangiospore suspension $\left(10 \mathrm{~mL} \mathrm{~kg}^{-1}\right.$ corresponding to an initial inoculum level of $10^{6} \mathrm{CFU} \mathrm{\textrm {g } ^ { - 1 }}$ beans), viable sporangiospores of $R$. microsporus were enumerated as colony-forming units (CFU) as described previously (18). The beans ( $450 \mathrm{~g}$ ) were packed into hard plastic, perforated boxes $(205 \times 90 \times 45 \mathrm{~mm})$ and incubated for $72 \mathrm{~h}$. Fermented soybeans (tempe) were freeze-dried and milled (Ultra Centrifugal Mill ZM 200, Retsch $\mathrm{GmbH}$, Haan, Germany) using a $0.5 \mathrm{~mm}$ sieve and stored at $-20{ }^{\circ} \mathrm{C}$ until further processing.

Bioactivity Assay. Brush borders were isolated from epithelial cells of the intestine of early weaned pigs as described before (19). The concentration of brush border was between $10^{5}$ and $10^{6}$ brush border $\mathrm{mL}^{-1}$ in phosphate-buffered saline ( $\mathrm{pH}$ 7.2) (PBS). The brush borders were tested for adhesion of ETEC K88 strain ID 1000 and E. coli (O149:K91) strain ID1084 (source, ID-Lelystad, Lelystad, The Netherlands). The ETEC K88-positive (ID 1000) and K88-negative strains (ID1084) were grown overnight at $37^{\circ} \mathrm{C}$ in BHI. The cultures were centrifuged $(10 \mathrm{~min}, 3000 \mathrm{~g}$, $20^{\circ} \mathrm{C}$ ) and washed twice in PBS, followed by suspension of the pellets in PBS to an optical density of 0.75 correlating with a concentration of $10^{9}$ CFU mL ${ }^{-1}$.

Freeze-dried fractions of tempe extracts $(10 \mathrm{mg})$ were suspended in $1 \mathrm{~mL}$ of PBS ( $1 \mathrm{w} / \mathrm{v} \%)$, mixed for $1 \mathrm{~h}$, and centrifuged (10 min, $10000 \mathrm{~g}$, $\left.20^{\circ} \mathrm{C}\right)$. Dilutions of the supernatants $(0.25$ and $0.1 \mathrm{w} / \mathrm{v} \%)$ were prepared in PBS. Aliquots $(30 \mu \mathrm{L})$ of each of the three solutions were mixed with $30 \mu \mathrm{L}$ of bacterial suspension and $30 \mu \mathrm{L}$ of brush borders and incubated at room temperature with continuous gentle shaking for $1 \mathrm{~h}$. The number of bacteria adhering to 12 brush borders, each derived from a single epithelial cell, was determined by phase contrast microscopy. The percentage adhesion was calculated as the average number of ETEC K88 per brush border relative to a PBS control.

Preparation of Fraction "Active 1". The tempe extracts were characterized by measuring the bioactivity after different treatments, that is, defatting, protease treatment, heating, and filtration, had been applied. Defatting was performed by three consecutive additions of hexane (1:10 (w/v) tempe/hexane) followed by filtration through a folded paper filter (Schleicher \& Schuell GmbH, Dassel, Germany) and air-drying, all at $20^{\circ} \mathrm{C}$. Tempe extracts were prepared by suspending $75 \mathrm{~g}$ of defatted tempe powder in $1 \mathrm{~L}$ of distilled water and stirring for $1 \mathrm{~h}$ at room temperature while the $\mathrm{pH}$ was adjusted to $\mathrm{pH} 8.0$ with $2 \mathrm{M} \mathrm{NaOH}$ every $30 \mathrm{~min}$. The soluble tempe material was obtained by collection of the supernatant after centrifugation $\left(30 \mathrm{~min}, 25000 \mathrm{~g}, 20{ }^{\circ} \mathrm{C}\right)$. The supernatant was filtered through a folded paper filter followed by a second centrifugation step.

Heat treatment was done by heating the extract for $15 \mathrm{~min}$ at $100^{\circ} \mathrm{C}$. For protease enzyme treatment, proteinase $\mathrm{K}$ or Pronase $\mathrm{E}$ was added $(0.01 \% \mathrm{w} / \mathrm{v})$ and incubated overnight at room temperature, followed by heating for $10 \mathrm{~min}$ to inactivate the enzymes. Then, the extracts were filtered using centrifugal filters with a membrane cutoff of $30 \mathrm{kDa}$ (Centriprep YM-30, Millipore, Billerica, MA). Both filtrates and retentates were freeze-dried and used for the bioactivity assay. Also, combinations of treatments were performed (see Figure 2 for combinations of treatments) and tested for bioactivity. Finally, the so-called fraction active 1 was obtained by a combination of defatting, filtration, proteinase $\mathrm{K}$ treatment, and heating. Figure 1 shows the order of treatments to obtain fraction active 1 .

Enzyme Treatments of Fraction Active 1. Freeze-dried fraction active $1\left(10 \mathrm{mg} \mathrm{mL}^{-1}\right)$ was solubilized in $20 \mathrm{mM} \mathrm{NaOAc} \mathrm{buffer} \mathrm{(pH} \mathrm{5.0).}$ Powdered enzymes $\left(10 \mathrm{mg} \mathrm{mL}^{-1}\right)$ were solubilized in NaOAc buffer $(\mathrm{pH}$ 5.0). Carbohydrases (Table 1) were added $(20 \mu \mathrm{L})$ each to $1 \mathrm{~mL}$ of fraction active 1 solution, and the mixture was incubated overnight at room temperature $\left(20^{\circ} \mathrm{C}\right)$ followed by heating for $10 \mathrm{~min}$ at $100^{\circ} \mathrm{C}$.

After enzyme incubations, the samples were tested for bioactivity, and carbohydrate molecular weight distributions were determined. The molecular weight distribution was determined by high-performance size exclusion chromatography (HPSEC) using an Ultimate 3000 HPLC system (Dionex, Sunnyvale, CA). Freeze-dried fractions were dissolved in $0.2 \mathrm{M}$ sodium nitrate $\left(5 \mathrm{mg} \mathrm{mL}^{-1}\right)$ and injected onto three TSK Gel columns in series (superAW 2500, superAW 3000, superAW4000, each $6 \mathrm{~mm} \times$ $150 \mathrm{~mm}$, Tosohaas, Stuttgart, Germany) in combination with a superAW Lguard column (Tosohaas). Elution took place at $30{ }^{\circ} \mathrm{C}$ with $0.2 \mathrm{M}$ sodium nitrate at $0.6 \mathrm{~mL} \mathrm{~min}{ }^{-1}$. The eluate was monitored using a refractive index (RI) detector (RI61, Shodex, New York, NY). The system was calibrated with pullulan standards (mass range from 180 to $4.04 \times$ $\left.10^{5} \mathrm{kDa}\right)$.

Next, the enzyme-treated samples were dialyzed using $3 \mathrm{kDa}$ filters (Microcon YM-3 3,000 NMWL, Millipore) to remove the degradation products. The monosaccharide composition of the remaining part was determined after hydrolysis using combined methanolysis/trifluoroacetic acid (TFA) hydrolysis. Sample solutions $\left(100 \mu \mathrm{L} ; 1 \mathrm{mg} \mathrm{mL}^{-1}\right)$ were dried 


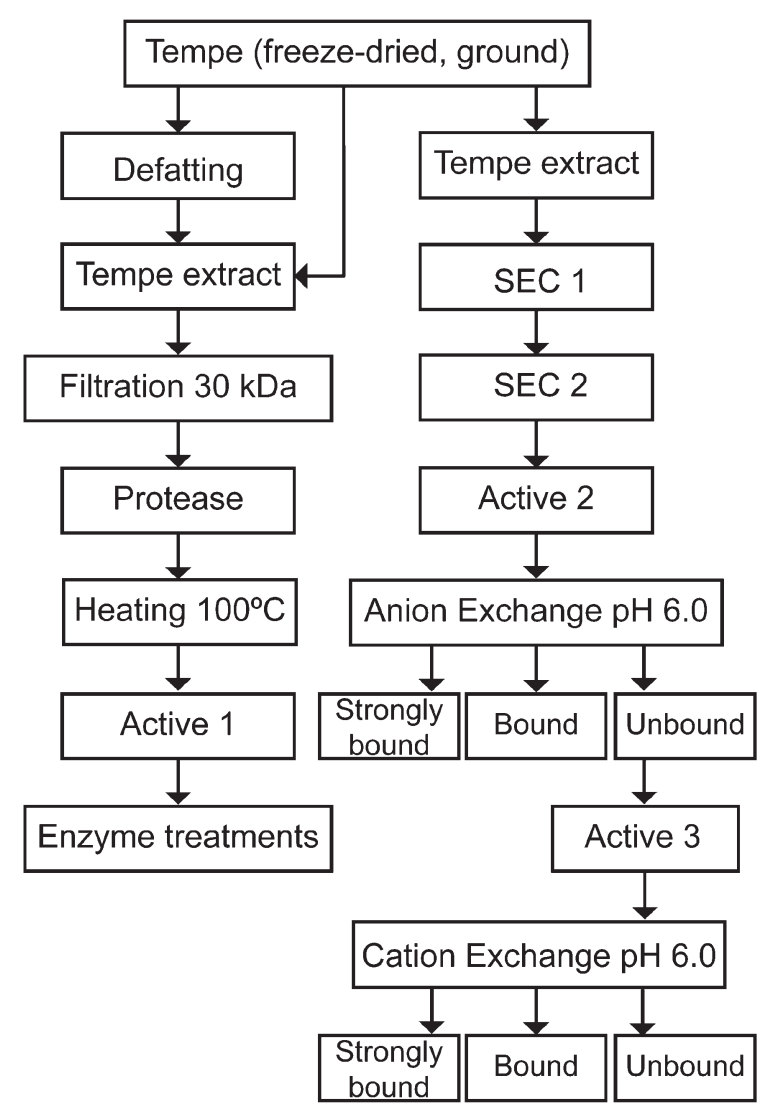

Figure 1. Schematic overview of the different treatments performed with the tempe extracts.

using a vacuum oven at $40^{\circ} \mathrm{C}$ during $4 \mathrm{~h}$. Next, $1.0 \mathrm{~mL}$ of $2 \mathrm{M} \mathrm{HCl}$ in dry methanol was added, flushed with nitrogen, and kept in screw-capped glass vials. The samples were incubated for $16 \mathrm{~h}$ at $80{ }^{\circ} \mathrm{C}$, followed by cooling, and evaporated under a stream of dry air at $40^{\circ} \mathrm{C}$. Subsequently, $0.5 \mathrm{~mL}$ of $2 \mathrm{M}$ TFA was added, and the samples were heat treated for $1 \mathrm{~h}$ at $121{ }^{\circ} \mathrm{C}$ in screw-capped glass vials in a heating block, followed by evaporation under a stream of dry air at $40^{\circ} \mathrm{C}$. The remaining material was washed twice with methanol, followed by evaporation, and finally dissolved in $1 \mathrm{~mL}$ of distilled water and diluted 10 times.

The monosaccharide composition was determined by high-performance anion exchange chromatography (HPAEC) using a Dionex ICS 3000 system connected with a PAD detector (Dionex ICS3000). A CarboPac PA-1 column $(2 \times 250 \mathrm{~mm}$, Dionex $)$ was used in combination with a CarboPac PA guard column $(2 \times 50 \mathrm{~mm}$, Dionex $)$. Samples were injected $(20 \mu \mathrm{L})$ onto the column and eluted for $30 \mathrm{~min}$ with Millipore water at a flow rate of $0.3 \mathrm{~mL} \mathrm{~min}^{-1}$, followed by a $15 \mathrm{~min}$ linear gradient of $0-40 \%(\mathrm{v} / \mathrm{v}) 1 \mathrm{M} \mathrm{NaOAc}$ in $0.1 \mathrm{M} \mathrm{NaOH}$, continued by 5 min of elution with $1 \mathrm{M} \mathrm{NaOAc}$ in $0.1 \mathrm{M} \mathrm{NaOH}$, followed by 5 min of elution with $0.1 \mathrm{M} \mathrm{NaOH}$. Finally, the column was equilibrated with Millipore water for $25 \mathrm{~min}$. As the postcolumn mobile phase, $0.5 \mathrm{M} \mathrm{NaOH}$ was used, to allow a proper detection, with a flow rate of $0.1 \mathrm{~mL} \mathrm{~min}^{-1}$. A standard was made with $1 \mathrm{mg} \mathrm{mL}^{-1}$ fucose, rhamnose, arabinose, xylose, galactose, glucose, mannose, glucuronic acid, and galacturonic acid and treated with the same procedure as the samples.

Preparation of Fraction "Active 2". For isolation of the bioactive substance in tempe, freeze-dried tempe powder $(200 \mathrm{~g})$ was suspended in $2 \mathrm{~L}$ of $35 \mathrm{mM}$ sodium phosphate buffer $(\mathrm{pH} 8.0)$ and stirred for $1 \mathrm{~h}$ at room temperature $\left(20^{\circ} \mathrm{C}\right)$ while the $\mathrm{pH}$ was adjusted every $30 \mathrm{~min}$. The insoluble parts were removed by centrifugation $\left(30 \mathrm{~min}, 25000 \mathrm{~g}, 20^{\circ} \mathrm{C}\right)$ followed by filtration of the supernatant through a folded paper filter and a second centrifugation step.

Size exclusion chromatography was performed using an Akta explorer system (GE Healthcare, Uppsala, Sweden). The supernatant (200 mL) was applied onto a Superdex 200 PG column (4.5 L, fractionation range from $1 \times 10^{4}$ to $6 \times 10^{5} \mathrm{Da}$, GE Healthcare) and eluted with $35 \mathrm{mM}$ sodium

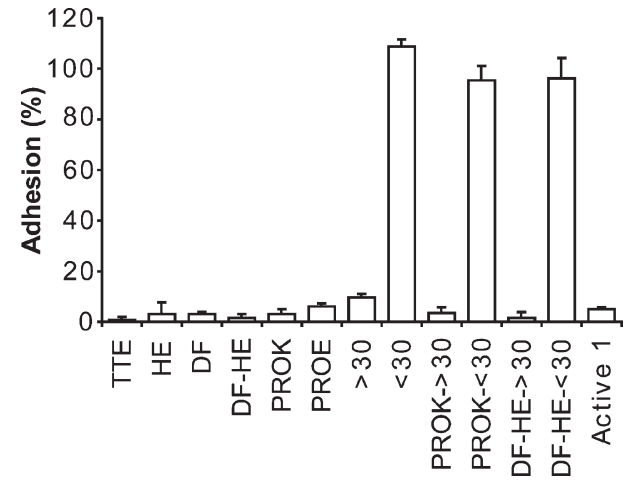

Figure 2. Bioactivity of tempe extracts after different treatments. Concentration of the extracts is $10 \mathrm{mg} \mathrm{mL}^{-1}$. Bars represent average adhesion ( $n=12$ ) expressed as percent adhesion compared to a control without any addition of tempe extracts. Error bars represent standard error of the mean. TTE, total tempe extract; HE, cooked tempe extract; DF, defatted tempe extract; PROK, tempe extract treated with proteinase K; PROE, tempe extract treated with Pronase $\mathrm{E} ;>30$, tempe extract $>30 \mathrm{kDA} ;<30$, tempe extract $<30 \mathrm{kDa}$; active 1 , combination of DF, $>30$, PROK, and $\mathrm{HE}$.

phosphate buffer $\left(\mathrm{pH} \mathrm{8.0)}\right.$ at a flow rate of $40 \mathrm{~mL} \mathrm{~min}^{-1}$. The eluate was monitored at 210 and $280 \mathrm{~nm}$, and fractions $(210 \mathrm{~mL})$ were collected. Five runs were performed, and fractions eluting at the same time were pooled. Pooled fractions were dialyzed against distilled water with a $12-14 \mathrm{kDa}$ dialyzing tube (Medicell international, London, U.K.) and freeze-dried. Freeze-dried fractions were tested for bioactivity.

To purify the active part, the active freeze-dried fractions that eluted between 1.9 and $2.9 \mathrm{~L}$ were pooled and solubilized in $250 \mathrm{~mL}$ of Millipore water. The solution was again applied onto the Superdex 200 PG, and fractions $(200 \mathrm{~mL})$ were collected. The fractions were dialyzed, freezedried, and tested for bioactivity. The active fractions were pooled and further described as fraction active 2 .

Fraction active $2\left(10 \mathrm{mg} \mathrm{mL}^{-1}\right)$ was dissolved in $35 \mathrm{mM}$ sodium phosphate buffer ( $\mathrm{pH}$ 6.0). Anion exchange was performed using a glass filter (diameter $=25 \mathrm{~mm}$ ) filled with $3 \mathrm{~mL}$ of the resin (DEAE CL 6B, GE Healthcare) on top of a vacuum Erlenmeyer. First, $3 \mathrm{~mL}$ of $35 \mathrm{mM}$ sodium phosphate buffer ( $\mathrm{pH} 6.0$ ) containing $0.5 \mathrm{M} \mathrm{NaCl}$ was eluted, to maximize exchangeable counterions, followed by washing of the resin with $15 \mathrm{~mL}$ of $35 \mathrm{mM}$ phosphate buffer ( $\mathrm{pH}$ 6.0). Next, $3 \mathrm{~mL}$ of fraction active 2 solution was added. The unbound fraction was collected, and $3.5 \mathrm{~mL}$ of $35 \mathrm{mM}$ sodium phosphate buffer ( $\mathrm{pH} 6.0$ ) containing $0.5 \mathrm{M} \mathrm{NaCl}$ was added to the resin and used to elute the bound material. Finally, $1 \mathrm{M} \mathrm{NaOH}$ was added to clean the resin and remove the so-called strongly bound fraction, which was immediately adjusted to $\mathrm{pH} 6.0$ with $\mathrm{HCl}$. The unbound, bound, and strongly bound fractions were dialyzed, freeze-dried, weighed, and tested for bioactivity.

The unbound fraction (active 3) was again dissolved in $35 \mathrm{mM}$ sodium phosphate and brought to $\mathrm{pH} 3.5$ with formic acid and eluted through the cationic resin SP Sepharose Fast Forward (GE Healthcare) with the same solutions as described for the anion exchange resin with the exception of using a $35 \mathrm{mM}$ sodium phosphate/formic acid buffer $(\mathrm{pH} 3.5)$ instead of the $35 \mathrm{mM}$ sodium phosphate buffer ( $\mathrm{pH}$ 6.0). The fractions collected were dialyzed, freeze-dried, weighed, and tested for bioactivity.

\section{RESULTS}

Characterization of the Active Component in Tempe. Different treatments were performed to characterize the bioactive components in tempe. Figure 2 shows the bioactivity of the untreated tempe extracts as well as the extracts after heating (HE), defatting (DF), proteinase $\mathrm{K}$ and Pronase $\mathrm{E}$ treatment (PROK and PROE), and ultrafiltration $(<30$ or $>30)$. The results show that the activity remained after defatting, protease treatment, and heating at $100{ }^{\circ} \mathrm{C}$ of the extracts. Filtering with a cutoff membrane of $30 \mathrm{kDa}$ showed that all activity was found in the retentate, which contained all material $>30 \mathrm{kDa}$. Various treatments were combined, and bioactivity was present after the 
Table 2. Monosaccharide Composition after Degradation with Gammanase (GAM), Galactase + Arabinofuranosidase (GAL + ARA), Driselase (DRI), and Pectinex Ultra SP (PEC) and Dialysis

\begin{tabular}{lrlrllllllll}
\hline & \multicolumn{8}{c}{ monosaccharide $^{a}(\mathrm{~mol} \%)$} & & total \\
\cline { 2 - 9 } & Fuc & Rha & Ara & Gal & Glc & Man & Xyl & GalA & GlcA & sugars $^{b}(\%)$ \\
\hline active 1 & 6.3 & nd $^{c}$ & 29.6 & 25.2 & 3.6 & 9.5 & 7.4 & 14.1 & 4.4 & 48.0 \\
GAL + ARA & 7.8 & nd & 29.0 & 12.2 & 3.3 & 13.3 & 10.1 & 17.0 & 7.2 & 28.8 \\
DRI & 8.0 & nd & 32.8 & 12.4 & 3.3 & 11.7 & 7.5 & 18.7 & 5.7 & 52.0 \\
GAM & 9.8 & nd & 5.3 & 15.3 & 5.1 & 16.7 & 12.3 & 27.1 & 8.5 & 33.3 \\
PEC & 11.4 & nd & 7.1 & 10.4 & 5.5 & 9.6 & 28.0 & 12.0 & 16.2 & 13.6 \\
\hline
\end{tabular}

${ }^{a}$ Results are averages of two replicates. Fuc, fucose; Rha, rhamnose; Ara, arabinose; Gal, galactose; Glc, glucose; Man, mannose; Xyl, xylose; GalA, galacturonic acid; GlcA, glucuronic acid. ${ }^{b}$ Sugar content (w/w \%) of fraction analyzed. ${ }^{c}$ nd, not determined.

combination of defatting, protease treatment, heating at $100{ }^{\circ} \mathrm{C}$, and ultrafiltration and is presented as active 1 in Figure 2. The results on heating and protease treatment suggest that the bioactive component is not proteinaceous.

The monosaccharide composition of the polysaccharides present in fraction active 1 was determined. This fraction consists of $48 \%(\mathrm{w} / \mathrm{w})$ of carbohydrates. The main monosaccharides of this fraction were arabinose, galactose, and galacturonic acid as shown in Table 2. Next, fraction active 1 was treated with various carbohydrate-degrading enzymes (listed in Table 1), which were selected on the basis of the sugar composition (Table 2), and the remaining bioactivity was measured. The results are shown in Figure 3. After treatment with gammanase (GAM), Pectinex Ultra SP (PEC), and Liq+ (LIQ), the bioactivity was lost. The other enzyme-treated extracts remained bioactive. The enzymatic degradation of the tempe extracts was then evaluated with HPSEC. Figure 4 shows the chromatograms of fraction active 1 (gray line) and the fractions active 1 after enzymatic degradation with the enzymes (black lines). The chromatograms of arabinofuranosidase A (ARA-A) and arabinofuranosidase B (ARA-B) are not shown because almost no degradation was observed. The chromatograms show different degradation profiles caused by the various enzymes. The chromatograms of GAM, PEC, and LIQ (which caused loss of bioactivity) showed a clear degradation, particularly of material eluted at low elution volumes (between 8 and $10 \mathrm{~min}$ ) in the chromatogram (size 65-796 kDa).

Two bioactive samples (treated with endogalactanase with arabinofuranosidases A and B (GAL + ARA) and Driselase (DRI)) and two nonactive samples (GAM and PEC) were selected and dialyzed. During dialyses the material $<3 \mathrm{kDa}$, which eluted around $12.5 \mathrm{~min}$, was removed. From the remaining material the sugar composition was determined (Table 2). After treatment with GAM, GAL + ARA, and PEC, a decrease in total sugars was observed (data not shown), which was expected because of the removal of the mono- and oligosaccharides released during dialysis. After incubation with DRI, the polysaccharides were not degraded to monosaccharides, but to intermediate sized molecules as shown in the chromatogram (Figure 4). After degradation with GAM and PEC, the fraction active 1 lost activity and showed a decrease in arabinose residues from 29.6 to 5.3 and 7.1 mol \%, respectively, whereas galactose decreased in all enzymetreated samples (Table 2). Despite the reduction in galactose, the GAL + ARA and DRI degraded samples remained bioactive. These two samples showed much higher molar proportions of arabinose than the GAM and PEC degraded samples. The molar proportion of galacturonic acid did not show any relationship with the decreased activity caused by GAM and PEC. Also, the recovery of individual sugars after enzyme treatment was calculated. The GAM and PEC treatment resulted in a removal of 88 and $93 \%(\mathrm{w} / \mathrm{w})$ of all arabinose residues

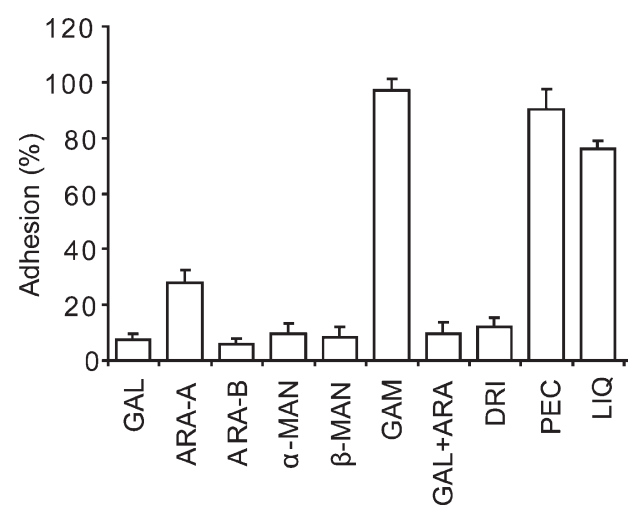

Figure 3. Bioactivity of fraction active 1 after treatment with various enzymes. Concentration of the extracts is $10 \mathrm{mg} \mathrm{mL}^{-1}$. Bars represent average adhesion $(n=12)$ expressed as percent adhesion compared to a control without any addition of tempe extracts. Error bars represent standard error of the mean. GAL, endo- $\beta$-1,4-galactanase; ARA-A, arabinofuranosidase A; ARA-B, arabinofuranosidase B; $\alpha-M A N, \alpha-$ mannosidase; $\beta$-MAN, endo- $\beta$-mannanase; GAM, gammanase; GAL + ARA, endo- $\beta$-1,4-galactanase and arabinofuranosidases $A$ and $B$; DRI, Driselase; PEC, Pectinex Ultra SP-L; LIQ, Rapidase Liq+.

present in the extract before the enzyme treatment, respectively (data not shown).

Purification of the Active Component. The tempe extract was purified (Figure 1) using two steps of size exclusion chromatography, labeled SEC 1 and SEC 2. Figure 5A shows the SEC elution pattern of tempe extract. In this figure the fractions collected and their corresponding activities are also indicated. The bioactivity was measured for the indicated fractions $1-11$, because the active part is $>30 \mathrm{kDa}$.

The activity was situated mainly in the intermediate part (fractions 4-6) of the chromatogram. At all three concentrations applied the adhesion was completely inhibited. The activities found are comparable to the activity of the total tempe extract (TTE) applied at $1 \%(\mathrm{w} / \mathrm{v})$, and these fractions even had a stronger adhesion inhibition capacity at the lower concentrations. This concentration effect was also observed in the fractions that are eluted before or just after the most active fractions. The material of all runs eluting between 1.9 and $2.9 \mathrm{~L}$ (intermediate peaks) was pooled and again applied onto the SEC column. The resulting elution pattern with the fractions collected and corresponding bioactivities is shown in Figure 5B. Fractions $4-6$ had the highest activities. They were located just before the main peak in the chromatogram; thereafter, the inhibition activity decreased quickly.

After SEC 2, the active material eluted between 1.8 and $2.4 \mathrm{~L}$ (fractions 4-6) was pooled and denoted fraction active 2. This material was eluted through an anion exchange resin column. Unbound, bound, and strongly bound fractions were collected, representing 38,13 , and $29 \%(\mathrm{w} / \mathrm{w})$ of the starting material, respectively. The bioactivity was measured, and fraction active 2 showed an adhesion of $11.1 \pm 3.6 \%$ (average \pm SEM) at a concentration of $0.1 \%(\mathrm{w} / \mathrm{v})$ extract. The unbound material showed an adhesion of $14.0 \pm 3.8 \%$ (average \pm SEM), and the bound and strongly bound fractions, $70.0 \pm 4.1$ and $99.3 \pm 7.5 \%$, respectively. Obviously, the bioactive material was present in the unbound material, and this part is called active 3. Subsequently, the fraction active 3 was applied onto a cation exchange column. Again, unbound, bound, and strongly bound fractions were collected, representing 14,38 , and $32 \%(\mathrm{w} / \mathrm{w})$ of the material loaded onto the column, respectively. The bioactivity was measured, and the highest inhibition activity was found in the 


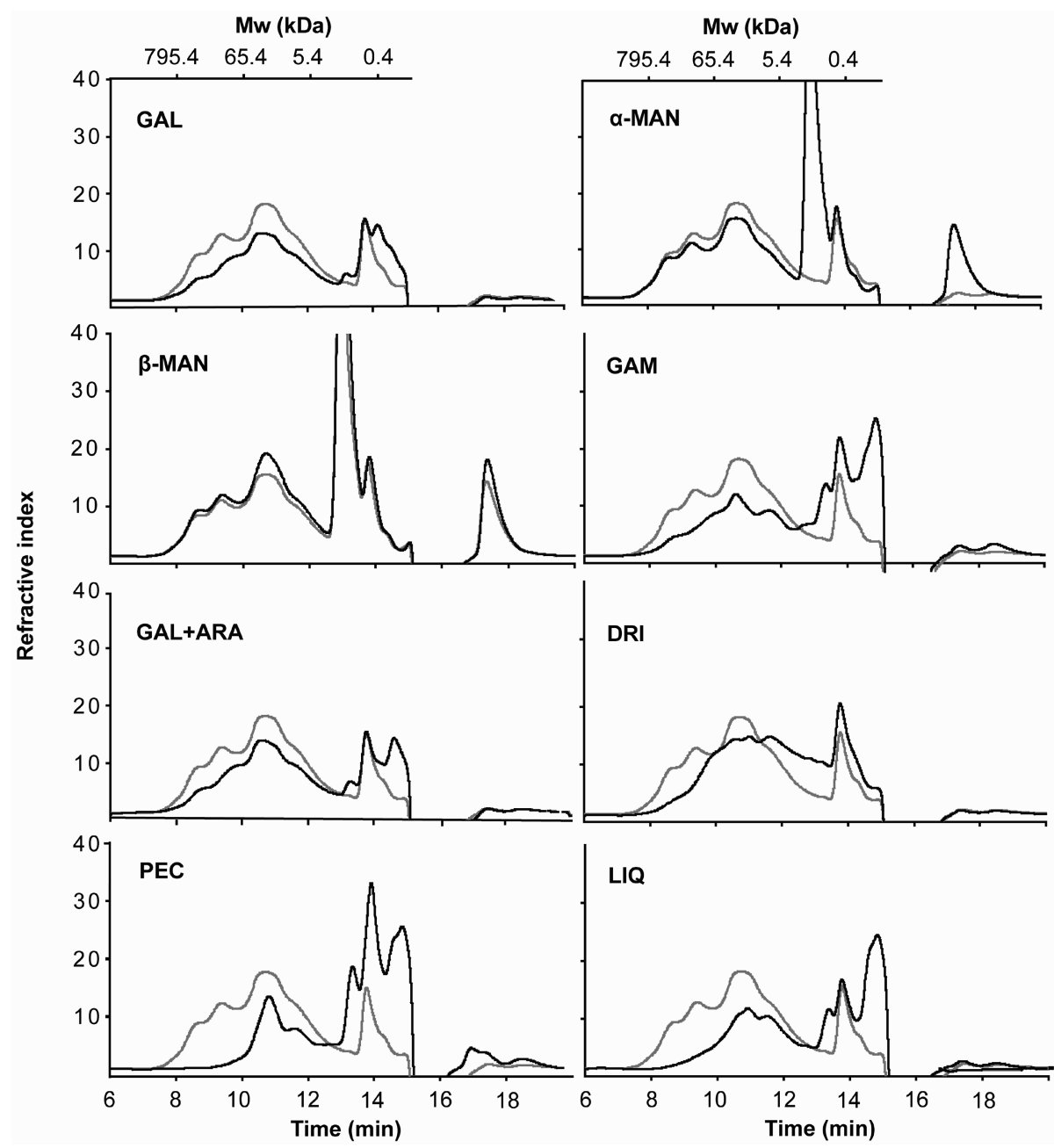

Figure 4. High-performance size exclusion chromatography of tempe extract (gray lines) and tempe treated with various enzymes (black lines). GAL, endo- $\beta$ 1,4-galactanase; $\alpha$-MAN, $\alpha$-mannosidase; $\beta$-MAN, endo- $\beta$-mannanase; GAM, gammanase; GAL + ARA, endo- $\beta$-1,4-galactanase and arabinofuranosidases A and B; DRI, Driselase; PEC, Pectinex Ultra SP-L; LIQ, Rapidase Liq+.

unbound material, $36.0 \pm 5.2 \%$ (average \pm SEM), compared with the bound and strongly bound materials, $84.0 \pm 11.5$ and $74.0 \pm 7.2 \%$, respectively, all at a concentration of $0.1 \%(\mathrm{w} / \mathrm{v})$ extract. Because part of the bioactivity was lost by the cationic exchange, we continued our experiments with the bioactive fraction active 3 .

Monosaccharide analysis was performed on fraction active 3 (Table 3). This fraction contained $59 \%(\mathrm{w} / \mathrm{w})$ sugars, which is higher than found in fraction active 1 (Table 2). Also, it exhibited a higher molar proportion $(50 \%)$ of arabinose than fraction active 1 . The ratio between arabinose and galactose moieties had changed from $1.2: 1$ to $2.7: 1$ for active 1 and active 3 , respectively.

\section{DISCUSSION}

We examined the chemical component(s) that protect intestinal cells from adhesion of ETEC bacteria. The bioactivity was tested on piglet intestinal brush border cells, but it is also active in inhibiting adhesion to human cells (16). The fractions of the first size exclusion chromatographic separation (SEC 1) experiment were also tested for their inhibition capacities to human Caco-2 intestinal cells. Results showed activity in fractions 5 and 6 with an inhibition of the adhesion of ETEC K88 to the intestinal epithelial cells of $60 \%$ (no further data shown). Earlier research found an inhibition of adhesion to Caco- 2 cells by total tempe extracts of almost $50 \%$, which may possibly reduce ETECinduced diarrhea in humans (16).
Because our earlier research $(13,14)$ had shown that the protective effect of tempe against ETEC-induced diarrhea was not diminished by in vitro or in vivo digestion, we used nondigested tempe extracts in this study for reasons of convenience and to avoid purification difficulties.

After ultafiltration of the tempe extracts, the bioactive component was recovered in the $>30 \mathrm{kDa}$ fraction. Also, the SEC 1 and SEC 2 experiments showed that the bioactive component is intermediate in size. In the research of Kiers et al. the bioactive component was recovered in the $>5 \mathrm{kDa}$ fraction (13). They found that high molecular mass $(>5 \mathrm{kDa})$ predigested and undigested tempe extracts showed equal protection against ETEC-induced fluid loss. The HPSEC patterns of these predigested and undigested tempe extracts were also identical in the high molecular weight part (13).

Tempe contains a diversity of microbial enzyme activities. Proteolytic enzyme activity in the gut could degrade intestinal receptors for ETEC as was shown before for bromelain (20). After heating of the tempe extracts, the proteolytic enzymes were inactivated (data not shown). Nevertheless, the tempe extracts were still bioactive after heating at $100{ }^{\circ} \mathrm{C}$ (Figure 2); thus, we concluded that the proteolytic enzyme activity was not responsible for the bioactivity.

Furthermore, it was shown that the bioactive component was not removed by defatting the tempe extract and that the bioactivity was not influenced by two broad spectrum proteolytic 

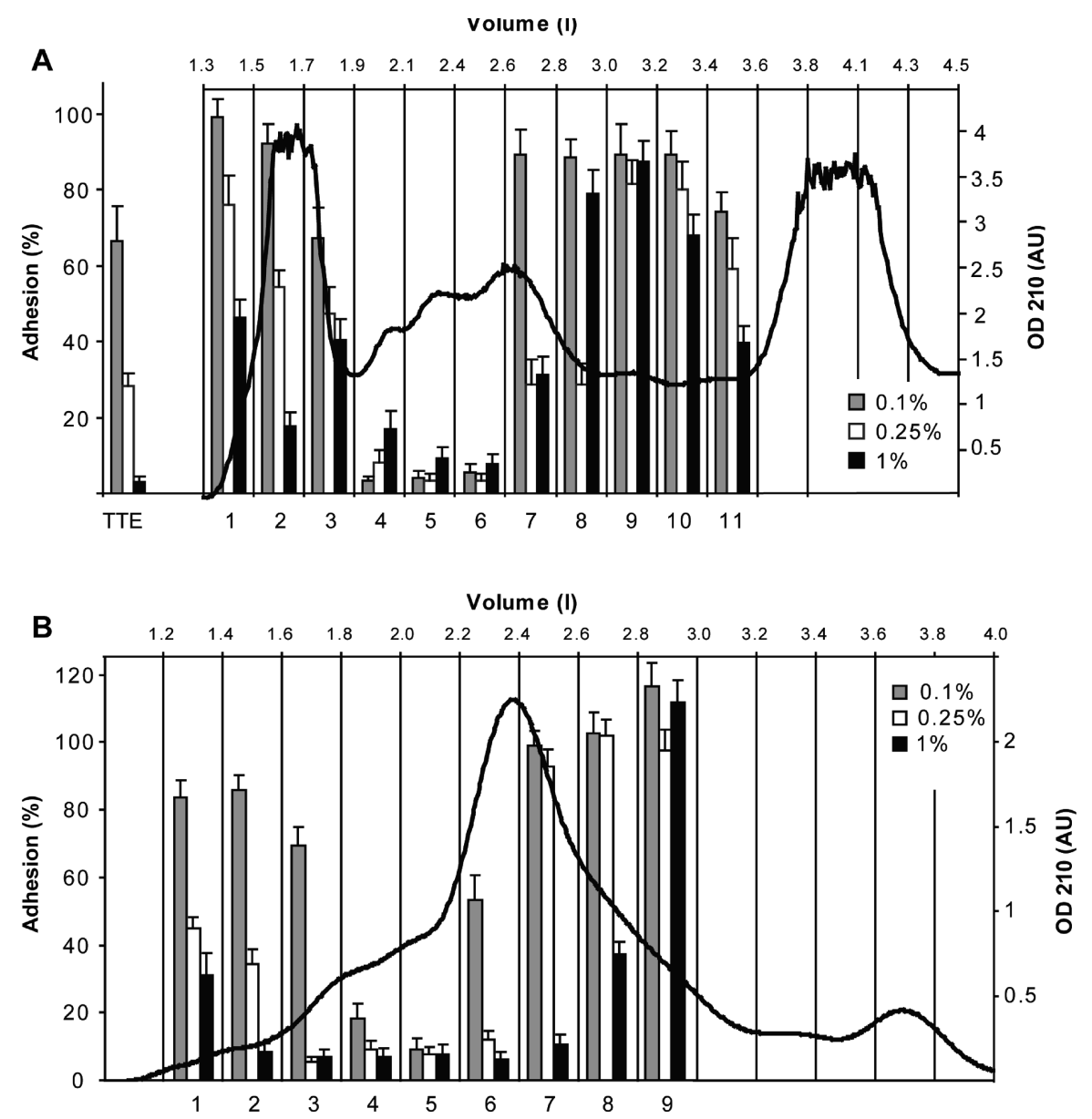

Figure 5. Size exclusion elution patterns of SEC 1 and SEC 2 with corresponding bioactivities: (A) SEC 1; (B) SEC 2 . TTE, total tempe extract. The lower $X$-axis represents the fraction numbers; the upper $X$-axis represents the elution volume. Bioactivity is measured in three concentrations, $0.1,0.25$, and $1 \%$ $(w / v)$. Bars represent average adhesion $(n=12)$ expressed as percent adhesion compared to a control without any addition of tempe extracts. Error bars represent the standard error of the mean.

Table 3. Monosaccharide Composition of Fraction Active 3

\begin{tabular}{ccccc}
\hline \multicolumn{4}{c}{ monosaccharide $^{a}(\mathrm{~mol} \%)$} \\
\cline { 2 - 4 } Fuc Rha Ara Gal Glc Man Xyl GalA GlcA total sugars ${ }^{b}(\%)$
\end{tabular}

$\begin{array}{lllllllllll}\text { active } 3 & 1.5 & \mathrm{nd}^{c} & 50.7 & 19.0 & 7.4 & 21.0 & \text { nd } & 0.2 & 0.2 & 56.4\end{array}$

${ }^{a}$ Results are averages of two replicates. Fuc, fucose; Rha, rhamnose; Ara, arabinose; Gal, galactose; Glc, glucose; Man, mannose; Xyl, xylose; GalA, galacturonic acid; GlcA, glucuronic acid. ${ }^{b}$ Total sugar expressed as weight $\%$ of the total fraction. ${ }^{c}$ nd, not determined.

enzymes. Although the fraction active 1 did not contain carbohydrates only, these findings make it unlikely that the active component was either proteinaceous or lipidic.

Carbohydrates have been described to prevent infection with bacterial pathogens by competitive inhibition (6). More specifically, soy polysaccharides have also been shown to reduce the duration of diarrhea in children (21). Previous research on tempe adhesion inhibition indicated that inhibition of adhesion by tempe extracts is caused by an interaction between the ETEC bacteria and the tempe extracts (16). The interaction could be caused by adhesion between the fimbriae of the ETEC and carbohydrate epitopes that are structurally similar to the binding sites on the epithelial cells. This strengthens the hypothesis that the bioactive component is made up of carbohydrates.

Tempe contains cell wall polysaccharides from different origins: (1) from soybeans and (2) from the mold R. microsporus. Furthermore, tempe is rich in lactic acid bacteria. The bioactivity of the tempe extracts is enhanced during fermentation (16). This can be due to the growth of the mold or lactic acid bacteria or the degradation of macromolecules during fermentation.

Previously, we investigated (22) the bioactivity of tempe extracts produced with various substrates and the same starter pure culture. All leguminous fermented substrates were bioactive, whereas cereal-derived tempe products (which allowed a similar mycelial growth of Rhizopus) showed no bioactivity at all. Also, after inoculation of soybeans with lactic acid bacteria, bioactivity was not induced (22). These results suggest that the active component is released or formed by enzymatic breakdown from leguminous substrates.

Carbohydrates in soybeans contain mainly cell wall polysaccharides and the small sugars fructose, raffinose, and stachyose. These small sugars were removed during soaking, cooking, and partially by fermentation of the soybeans, and the remaining sugars were removed during filtration of the processing of fraction active 1 . The cell wall polysaccharides of soy are (partially) degraded during fermentation by the enzymes of the mold, which leads to enhanced solubility (23). The major carbohydrases of Rhizopus oligosporus grown on tempe include polygalacturonases, endocellulases, xylanases, and arabinanases (24). During fermentation the arabinogalactan and pectin fractions are predominantly solubilized (25). The major monosaccharide constituents in soy cell walls are galactose, glucose (from cellulose), arabinose, and galacturonic acid (26). Fraction active 1 is rich in arabinose, galactose, and galacturonic acid, which corresponds to 
the observation (25) of degradation or solubilization of pectin and arabinogalactan during fermentation.

The monosaccharide composition of the remaining polysaccharides in fraction active 1 after enzyme treatment showed that arabinose is an important component of the bioactive fractions. Enzymes that were able to degrade the arabinose-containing polysaccharides were all responsible for a loss of bioactivity, whereas the enzymic removal of galactose and galacturonic acid from the polysaccharides did not specifically cause a loss of activity.

After further purification of the active component with SEC and anion exchange (fraction active 3), an increase in molar proportion of the arabinose in the active fraction was also observed, which strengthens this statement. Research published elsewhere $(4,6,7)$ indicated that sugars other than arabinose may inhibit bacterial adhesion by interaction with the bacteria.

Arabinose, in addition to galactose, is an important monosaccharide in pectic cell wall polysaccharides of soybeans. Arabinose is especially present in the side chains of rhamnogalacturonans. Rather long arabinan side chains with degrees of polymerization of up to $30-35$, in addition to the (arabino)galactan side chains, have been reported (27). It is assumed that some structural epitopes of such arabinans or arabinogalactans are responsible for the bioactivity in tempe. During fermentation these structures become more soluble and are thereby more accessible to the intestinal cells.

Some commercial carbohydrates (mannose, arabinose, galactose, arabinogalactan, arabinan) were tested, but they were not bioactive (no further data shown).

Because the bioactivity is found only in fractions $>30 \mathrm{kDa}$ and is lost after incubation with some enzyme mixtures, only a partial degradation of cell wall polysaccharides is needed to obtain the required structure needed for adhesion to ETEC in competition with the binding sites of the epithelial cells.

In conclusion, it is likely that the active component is of carbohydrate nature, containing arabinose. The bioactive component originates from arabinan or arabinogalactan chains of the pectic cell wall polysaccharides of the soybeans and is released or formed during fermentation by enzymatic modifications. Further research to fully characterize the chemical structure of the bioactive component is needed. A full characterization could open new possibilities for producing the bioactive component, probably via the addition of specific enzymes liberating the arabinose-containing medium-weight polysaccharides, which makes it a potential ingredient in food or feed matrices.

\section{LITERATURE CITED}

(1) Nataro, J. P.; Kaper, J. B. Diarrheagenic Escherichia coli. Clin. Microbiol. Rev. 1998, 11 (1), 142-201.

(2) Qadri, F.; Svennerholm, A. M.; Faruque, A. S.; Sack, R. B. Enterotoxigenic Escherichia coli in developing countries: epidemiology, microbiology, clinical features, treatment, and prevention. Clin. Microbiol. Rev. 2005, 18 (3), 465-483.

(3) Nagy, B.; Fekete, P. Z. Enterotoxigenic Escherichia coli in veterinary medicine. Int. J. Med. Microbiol. 2005, 295 (6-7), 443-454.

(4) Ofek, I.; Hasty, D. L.; Sharon, N. Anti-adhesion therapy of bacterial diseases: prospects and problems. FEMS Immunol. Med. Microbiol. 2003, 38 (3), 181-191.

(5) Pieters, R. J. Intervention with bacterial adhesion by multivalent carbohydrates. Med. Res. Rev. 2007, 27 (6), 796-816.

(6) Sharon, N. Carbohydrates as future anti-adhesion drugs for infectious diseases. Biochim. Biophys. Acta 2006, 1760, 527-537.

(7) Bode, L. Recent advances on structure, metabolism, and function of human milk oligosaccharides. J. Nutr. 2006, 136 (8), 21272130 .
(8) Blomberg, L.; Henriksson, A.; Conway, P. L. Inhibition of adhesion of Escherichia coli K88 to piglet ileal mucus by Lactobacillus spp. Appl. Environ. Microbiol. 1993, 59, 34-39.

(9) Fujiwara, S.; Hashiba, H.; Hirota, T.; Forstner, J. F. Inhibition of the binding of enterotoxigenic Escherichia coli Pb176 to human intestinal epithelial cell line HCT-8 by an extracellular protein fraction containing BIF of Bifidobacterium longum SBT2928: suggestive evidence of blocking of the binding receptor gangliotetraosylceramide on the cell surface. Int. J. Food Microbiol. 2001, 67 $(1-2), 97-106$.

(10) Nout, M. J. R.; Kiers, J. L. Tempe fermentation, innovation and functionality: update into the third millenium. J. Appl. Microbiol. 2005, 98 (4), 789-805.

(11) Partridge, G. G. The role and efficacy of carbohydrase enzymes in pig nutrition. In Enzymes in Farm Animals; Bedford, M. R., Partridge, G. G., Eds.; CAB International: Wallingford, U.K., 2001; pp 161-198.

(12) Kiarie, E. G.; Slominski, B. A.; Krause, D. O.; Nyachoti, C. M. Nonstarch polysaccharide hydrolysis products of soybean and canola meal protect against enterotoxigenic Escherichia coli in piglets. J. Nutr. 2008, 138 (3), 502-508.

(13) Kiers, J. L.; Meijer, J. C.; Nout, M. J. R.; Rombouts, F. M.; Nabuurs, M. J. A.; Van der Meulen, J. Effect of fermented soya beans on diarrhoea and feed efficiency in weaned piglets. J. Appl. Microbiol. 2003, 95 (3), 545-552.

(14) Kiers, J. L.; Nout, M. J. R.; Rombouts, F. M.; Nabuurs, M. J.; Van der Meulen, J. A high molecular weight soluble fraction of tempeh protects against fluid losses in Escherichia coli-infected piglet small intestine. Br. J. Nutr. 2007, 98 (2), 320-325.

(15) Kiers, J. L.; Nout, M. J. R.; Rombouts, F. M.; Nabuurs, M. J. A.; Van der Meulen, J. Inhibition of adhesion of enterotoxic Escherichia coli K88 by soya bean tempe. Lett. Appl. Microbiol. 2002, 35, 311-315.

(16) Roubos-van den Hil, P. J.; Nout, M. J. R.; Beumer, R. R.; van der Meulen, J.; Zwietering, M. H. Fermented soya bean (tempe) extracts reduce adhesion of enterotoxigenic Escherichia coli to intestinal epithelial cells. J. Appl. Microbiol. 2009, 106 (3), 1013-1021.

(17) Nout, M. J. R.; De Dreu, M. A.; Zuurbier, A. M.; Bonants-Van Laarhoven, T. M. G. Ecology of controlled soyabean acidification for tempe manufacture. Food Microbiol. 1987, 4, 165-172.

(18) Nout, M. J. R.; Notermans, S.; Rombouts, F. M. Effect of environmental conditions during soya-bean fermentation on the growth of Staphhylococcus aureus and production and thermal stability of enterotoxins A and B. Int. J. Food Microbiol. 1988, 7, 299-309.

(19) Sellwood, R.; Gibbons, R. A.; Jones, G. W.; Rutter, J. M. Adhesion of enteropathogenic Escherichia coli to pig intestinal brush borders: the existence of two pig phenotypes. J. Med. Microbiol. 1975, 8 (3), 405-411.

(20) Chandler, D. S.; Mynott, T. L. Bromelain protects piglets from diarrhoea caused by oral challenge with $\mathrm{K} 88$ positive enterotoxigenic Escherichia coli. Gut 1998, 43, 196-202.

(21) Brown, K. H.; Perez, F.; Peerson, J. M.; Fadel, J.; Brunsgaard, G.; Ostrom, K. M.; MacLean, W. C., Jr. Effect of dietary fiber (soy polysaccharide) on the severity, duration, and nutritional outcome of acute, watery diarrhea in children. Pediatrics 1993, 92 (2), 241-247.

(22) Roubos-van den Hil, P. J.; Nout, M. J. R.; van der Meulen, J.; Gruppen, H. Bioactivity of tempe by inhibiting adhesion of ETEC to intestinal cells, as influenced by fermentation and starter pure cultures. Food Microbiol. 2010, 27, 638-644.

(23) Kiers, J. L.; Van Laeken, A. E.; Rombouts, F. M.; Nout, M. J. R. In vitro digestibility of Bacillus fermented soya bean. Int. J. Food Microbiol. 2000, 60 (2-3), 163-169.

(24) Sarrette, M.; Nout, M. J. R.; Gervais, P.; Rombouts, F. M. Effect of water activity on production and activity of Rhizopus oligosporus polysaccharidases. Appl. Microbiol. Biotechnol. 1992, 37, 420-425.

(25) De Reu, J. C.; Linssen, V. A. J. M.; Rombouts, F. M.; Nout, M. J. R. Consistency, polysaccharidase activities and non-starch polysaccharides content of soya beans during tempe fermentation. J. Sci. Food Agric. 1997, 73, 357-363.

(26) Huisman, M. M. H.; Schols, H. A.; Voragen, A. G. J. Cell wall polysaccharides from soybean (Glycine max) meal. Isolation and characterisation. Carbohydr. Polym. 1998, 37, 87-95. 
(27) Huisman, M. M. H. Elucidation of the chemical fine structure of polysaccharides from soybean and maize kernel cell walls. Ph.D. thesis, Wageningen University, Wageningen, The Netherlands, 2000.

(28) Van de Vis, J. W.; Searle-van Leeuwen, M. J. F.; Siliha, H. A.; Kormelink, F. J. M.; Voragen, A. G. J. Purification and characterization of endo-1,4- $\beta$-D-galactanases from Aspergillus niger and Aspergillus aculeatus: use in combination with arabinanases from Aspergilus niger in enzymic conversion of potato arabinogalactan. Carbohydr. Polym. 1991, 16, 167-187.
(29) Rombouts, F.; Voragen, A.; Searle-van Leeuwen, M.; Geraeds, C.; Schols, H.; Pilnik, W. The arabinases of Aspergillus niger - purification and characterisation of two $\alpha$-L-arabinofuranosidases and an endo-1,5- $\alpha$-L-arabinanase. Carbohydr. Polym. 1988, 9, 25-47.

Received for review April 13, 2010. Revised manuscript received June 1, 2010. Accepted June 3, 2010. This research was financially supported by the Graduate School VLAG, Wageningen University, Wageningen, The Netherlands. 